\title{
Paleodietary and Paleoclimatic Reconstruction of Hipparion Fauna at 9 Ma From the Xunhua Basin on the Northeastern Tibetan Plateau
}

OPEN ACCESS

Edited by:

Yunfa Miao,

Northwest Institute of ECO-

Environment and Resources (CAS),

China

Reviewed by:

Xiangzhong Li,

Yunnan University, China

Jun Tian,

Tongji University, China

${ }^{*}$ Correspondence:

Bowen Song

bwsong1985@cug.edu.cn

Kexin Zhang

kx_zhang@cug.edu.cn

Specialty section:

This article was submitted to Quaternary Science, Geomorphology

and Paleoenvironment,

a section of the journal

Frontiers in Earth Science

Received: 31 May 2021

Accepted: 23 July 2021

Published: 04 August 2021

Citation:

Hu F, Song B, Sun Y, Huang W, Luo M,

Ji J, Lin Q, Algeo TJ and Zhang K (2021) Paleodietary and Paleoclimatic Reconstruction of Hipparion Fauna at 9 Ma From the Xunhua Basin on the

Northeastern Tibetan Plateau.

Front. Earth Sci. 9:717720.

doi: 10.3389/feart.2021.717720

\author{
Fei Hu ${ }^{1}$, Bowen Song ${ }^{1 *}$, Yuanyuan Sun ${ }^{2}$, Wei Huang ${ }^{3}$, Mansheng Luo ${ }^{4}$, Junliang $\mathrm{Ji}^{4}$, \\ Qixiang Lin ${ }^{5}$, Thomas J. Algeo ${ }^{4,6,7}$ and Kexin Zhang ${ }^{1,4 *}$
}

${ }^{1}$ Institute of Geological Survey, China University of Geosciences, Wuhan, China, ${ }^{2}$ Chengdu Center, China Geological Survey, Chengdu, China, ${ }^{3}$ Guangdong Geological Survey Institute, Guangzhou, China, ${ }^{4}$ State Key Laboratory of Biological and Environmental Geology, China University of Geosciences, Wuhan, China, ${ }^{5}$ School of Earth Sciences, China University of Geosciences, Wuhan, China, 'S State Key Laboratory of Geological Processes and Mineral Resources, China University of Geosciences, Wuhan, China, ${ }^{7}$ Department of Geology, University of Cincinnati, Cincinnati, OH, United States

Stable isotope analysis is pivotal for investigating the paleodiet and paleoecology of ancient mammals. Recently, a 9-Myr-old Hipparion fauna was discovered at an elevation of $\sim 2,200 \mathrm{~m}$ above sea level (a.s.l.) in the Xunhua Basin on the northeastern Tibetan Plateau. These fossils can provide key evidence for the ecosystem structure and regional paleoenvironmental reconstruction. Here we present carbon and oxygen isotopic compositions of 56 bulk and 85 serial tooth enamel samples from this fauna, which includes Hipparion platyodus Selve, Chilotherium sp. and Gazella gaudryi Schlosser. The enamel $-\delta^{13 \circ} \mathrm{C}$ values display a wide range of variation $(-11.4$ to $-5.0 \%$ ), with a mean value of $-8.9 \pm 1.0 \%$, indicating that the fauna consumed mainly $\mathrm{C}_{3}$ plants. However, the heaviest $\delta^{13} \mathrm{C}$ value of Hipparion (-5.0\%) suggests at least some consumption of $\mathrm{C}_{4}$ plants. Combined with pollen records, we infer that the Hipparion fauna in the Xunhua Basin was living in forest-grassland setting at $\sim 9 \mathrm{Ma}$. The reconstructed paleo-meteoric $\delta^{18} \mathrm{O}$ values of the Xunhua Basin at $\sim 9 \mathrm{Ma}$ are lower than the mean annual $\delta^{18} \mathrm{O}$ of presentday precipitation in this region, suggesting a wetter climate or stronger monsoonal influence than today. Hipparion fauna in the Xunhua Basin yield significantly higher mean values of $\delta^{13} \mathrm{C}$ and $\delta^{18} \mathrm{O}$ than contemporary fossils in the Linxia Basin to the east, which is attributed to rapid uplift of the Jishi Shan, blocking water vapor transport by the East Asian Summer Monsoon and making the climate of the Xunhua Basin relatively drier.

Keywords: carbon isotopes, oxygen isotopes, tooth enamel, late miocene, uplift, Jishi Shan

\section{INTRODUCTION}

Cenozoic sedimentary basins of the Tibetan Plateau have yielded abundant fossil mammals, whose reconstructed diets can provide valuable information about paleoenvironmental and paleoclimatic changes. Given the resistance of fossil mammal teeth to diagenetic alteration due to their high density and low porosity (Ayliffe et al., 1994; MacFadden and Cerling, 1994; Wang et al., 1994), the stable carbon and oxygen isotopic compositions of tooth enamel have proven to be a useful tool for 
inferring climate and environmental conditions such as vegetation cover, aridity, precipitation sources, and climate seasonality in the past (Cerling et al., 1993; Cerling et al., 1998; Levin et al., 2006; Wynn et al., 2012; Sun et al., 2021).

In recent decades, many stable isotope studies have been conducted on fossil materials from Miocene to Pliocene strata of the Tibetan Plateau (Wang and Deng, 2005; Biasatti et al., 2010; Biasatti et al., 2012; Biasatti et al., 2018; Zhang et al., 2012a; Deng et al., 2012; Ciner et al., 2015). Previous studies have focused mostly on issues of ecosystem structure and regional paleoenvironmental reconstruction. For instance, Zhang et al. (2012a) inferred that the presence of significant $\mathrm{C}_{4}$ biomass in the Qaidam Basin between 9.5 and $5 \mathrm{Ma}$ signified a wetter and warmer climate. Wang and Deng (2005) suggested that herbivores in the Linxia Basin fed predominantly on $\mathrm{C}_{3}$ plants before $2.5 \mathrm{Ma}$, and that a positive shift in both horse and rhino bulk $\delta^{18} \mathrm{O}$ recorded a shift to more arid conditions at $9.5 \mathrm{Ma}$.

The Xunhua Basin is located on the northeastern Tibetan Plateau in a climatically sensitive area, representing the transitional zone between the monsoonal coastal region to the east and the arid continental interior to the west. Much research has been conducted on climate change in the Xunhua Basin using stable isotopes (Hough et al., 2011), magnetostratigraphy (Ji et al., 2010), palynological data (Xu et al., 2015), ostracod data (Luo et al., 2010), clay mineralogy (Wang et al., 2010), and chemical weathering indices (Ye et al., 2010). Palynological studies in the Xunhua Basin indicate a long-lasting cooling trend beginning at $\sim 14 \mathrm{Ma}$. However, clay mineralogy and chemical weathering indices from the Xunhua Basin indicate arid conditions between 14.6 and $12.5 \mathrm{Ma}$, a relatively wetter stage between 12.5 and $8 \mathrm{Ma}$, and renewed climatic drying at $8 \mathrm{Ma}$. Thus, paleoclimate changes in the Xunhua Basin during the Late Miocene remain contentious.

Recently, we discovered an upper Miocene Hipparion fauna $(\sim 9 \mathrm{Ma})$ in the Xunhua Basin at an elevation of $\sim 2,200 \mathrm{~m}$ a.s.l. Mammal tooth enamel forms incrementally from the crown to the base of the tooth, recording variation in $\delta^{13} \mathrm{C}$ and $\delta^{18} \mathrm{O}$ values over time. Such isotopic series can provide excellent records of seasonal variation in diet and climate during tooth growth (Koch et al., 1995; Fricke and O'Neil, 1996; Fricke et al., 1998; Sharp and Cerling, 1998; Nelson, 2005; Sponheimer et al., 2006; Wang et al., 2008a). Stable carbon and oxygen isotopic analyses of our newly discovered fossil mammal teeth in the Xunhua Basin can provide not only useful proxies for reconstructing paleodiets and paleoecology but also a baseline for regional comparison with well-studied Hipparion faunas from the Linxia Basin (Wang and Deng, 2005; Biasatti et al., 2010, 2018) with the goal of better understanding the history of regional environmental and ecosystem changes on the northeastern Tibetan Plateau and their relationship to tectonics and global climate.

\section{GEOGRAPHIC AND GEOLOGICAL SETTING}

The Xunhua Basin, with an elevation between 1870 and 3,000 m, is surrounded by the east-west-trending Laji Shan to the north, the north-south-trending Jishi Shan to the east, and the
Zhamazari and West Qinling Shan to west and south, respectively (Figures 1A,B). The basin is located in middle latitudes, in a semi-arid region in which mean annual temperature is $\sim 8.5^{\circ} \mathrm{C}$ and mean annual precipitation is $264 \mathrm{~mm}$, of which $\sim 75 \%$ falls as monsoonal rain during the summer (IAEA/WMO, 2018).

The Xigou section (starting coordinates, N $35^{\circ} 49^{\prime} 30^{\prime \prime}$, E $102^{\circ} 30^{\prime} 00^{\prime \prime}, 1797 \mathrm{~m}$; ending coordinates, $\mathrm{N} 35^{\circ} 48^{\prime} 18^{\prime \prime}, \mathrm{E}$ $\left.102^{\circ} 26^{\prime} 10^{\prime \prime}, 2,344 \mathrm{~m}\right)$, located in the southeastern Xunhua Basin (Figure 1C), has well-exposed Miocene to Pliocene strata with an overall thickness of more than $600 \mathrm{~m}$, deposited without significant hiatuses (Figure 2). Our previous magnetostratigraphic study has determined a depositional age for this section of 14.6 to 5.0 Ma (Ji et al., 2010), with the following approximate formation ages: Dongxiang Formation (14.6-9.6 Ma), Liushu Formation (9.6-7.3 Ma), and Hewangjia Formation (7.3-5.0 Ma) (Figure 2). Many fossil mammals were collected at the base of the Liushu Formation within a 1-m-thick interval at 378-379 m, including Hipparion platyodus Selve (Figures 3A-E), Chilotherium sp. (Figures 3F-J), Gazella gaudryi Schlosser (Figures 3K-N), Gazella paotehensis, Gazella dorcadoides, Gazella sp., and Cervocerus sp. Based on the magnetostratigraphy of the Xigou section (Ji et al., 2010), the Hipparion fauna in the Xunhua Basin was found within chron C4An (Figure 2) and has an estimated age of 8.99-9.06 Ma based on linear interpolation between age tie-points (i.e., assuming a constant sedimentation rate). Because this age range is narrow and beyond the precision of our study, we herein report the age of the Hipparion fauna as $\sim 9 \mathrm{Ma}$.

\section{MATERIALS AND METHODS}

We selected 56 well-preserved fossils of herbivorous mammals including Hipparion platyodus Selve, Chilotherium sp., and Gazella gaudryi Schlosser for stable carbon and oxygen isotope analyses. We preferentially analyzed molars and premolars to overcome paleoecological bias from juvenile development (Bryant et al., 1996). However, many specimens of the fossil Chilotherium that we analyzed were so fragmentary that to identify them to genus was difficult. The tooth samples were prepared by scraping any dirt, dentine, or other material off the enamel. For bulk enamel samples, fine powder was drilled from a cleaned enamel surface evenly along the entire growth axis to make the sample more representative of the entire period of mineralization. In order to study whether local vegetation exhibited seasonal variations, serial enamel samples were obtained from nine selected Hipparion teeth by drilling in bands perpendicular to the growth axes of each tooth from crown to root with a rotary tool.

The enamel powder was then soaked in 5\% sodium hypochlorite $(\mathrm{NaOCl})$ to remove organic matter, followed by treatment with $1 \mathrm{M}$ acetic acid for at least $12 \mathrm{~h}$ to remove nonstructural carbonate, cleaning with distilled water via centrifugation at least three times, and finally freeze-drying. The enamel samples were the converted to $\mathrm{CO}_{2}$ by reaction with $100 \%$ phosphoric acid for approximately $72 \mathrm{~h}$ at $25^{\circ} \mathrm{C}$; the 

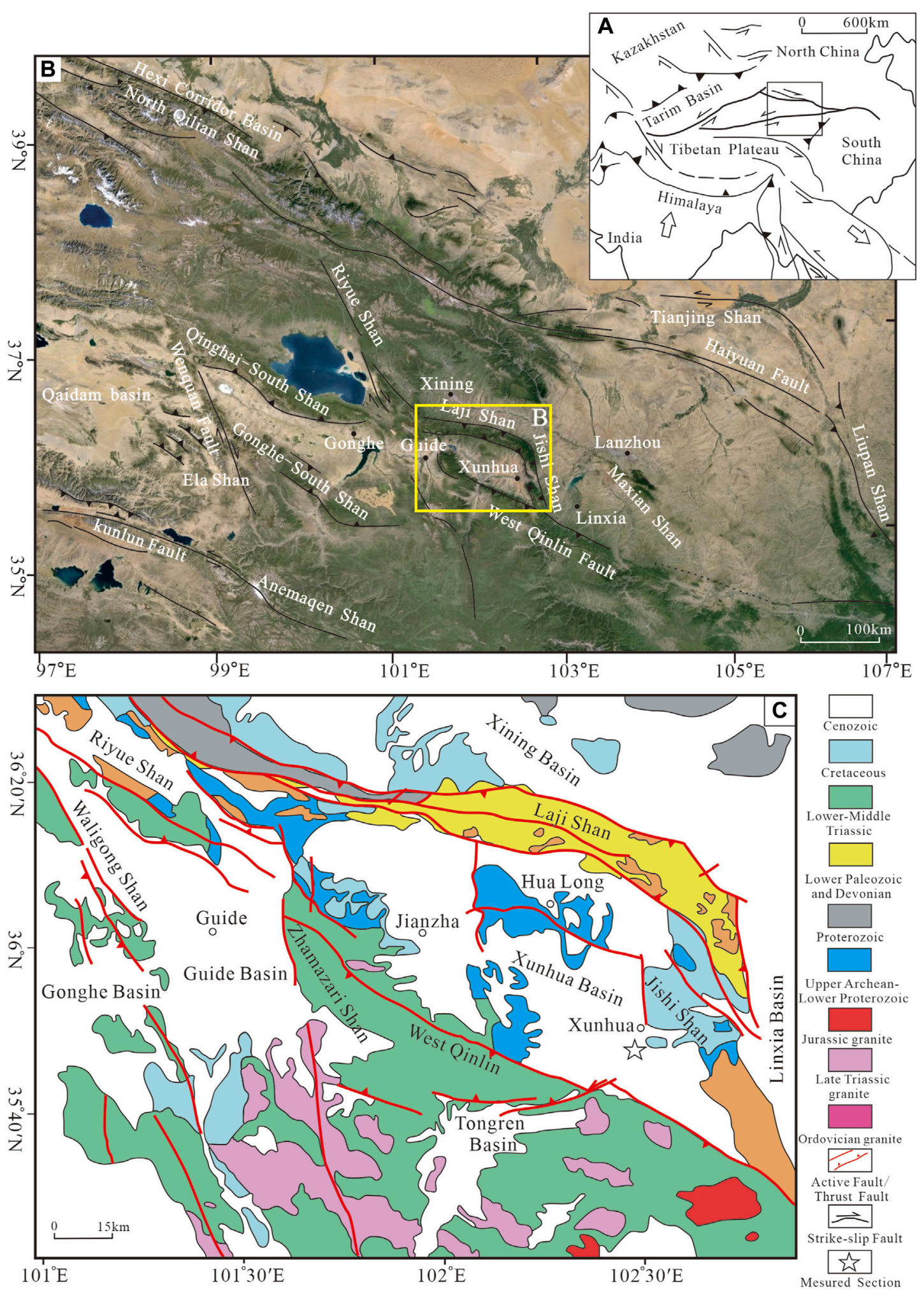

FIGURE 1 | Geological sketch maps showing the location and tectonic setting of the study area: (A) Location of the study area on Tibetan Plateau (modified from Yin and Harrison, 2000); (B) Tectonic sketch of Xunhua Basin; and (C) Detailed geological map of the Xunhua Basin (modified from Zhang et al., 2010) and the location of the measured section. 


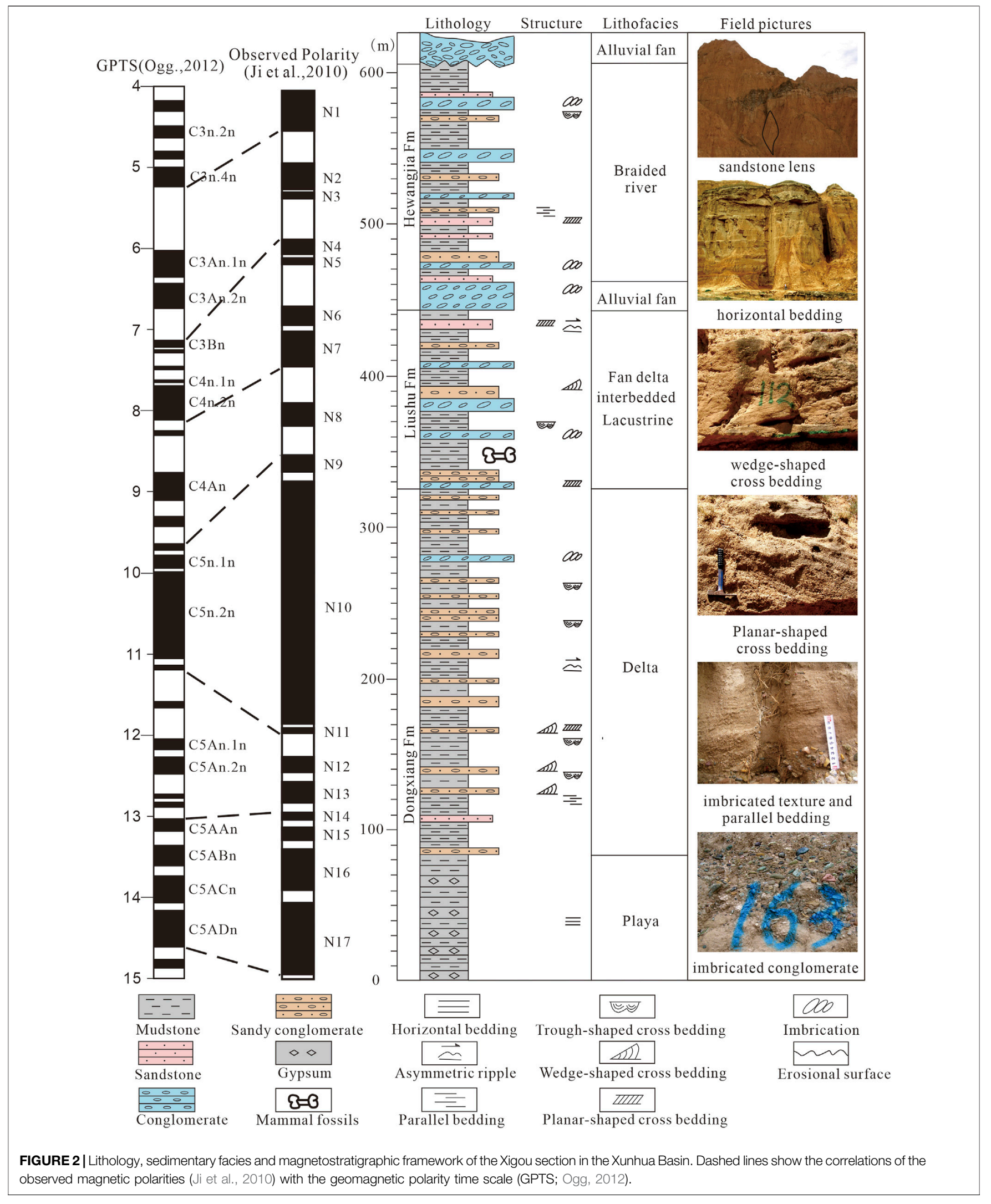




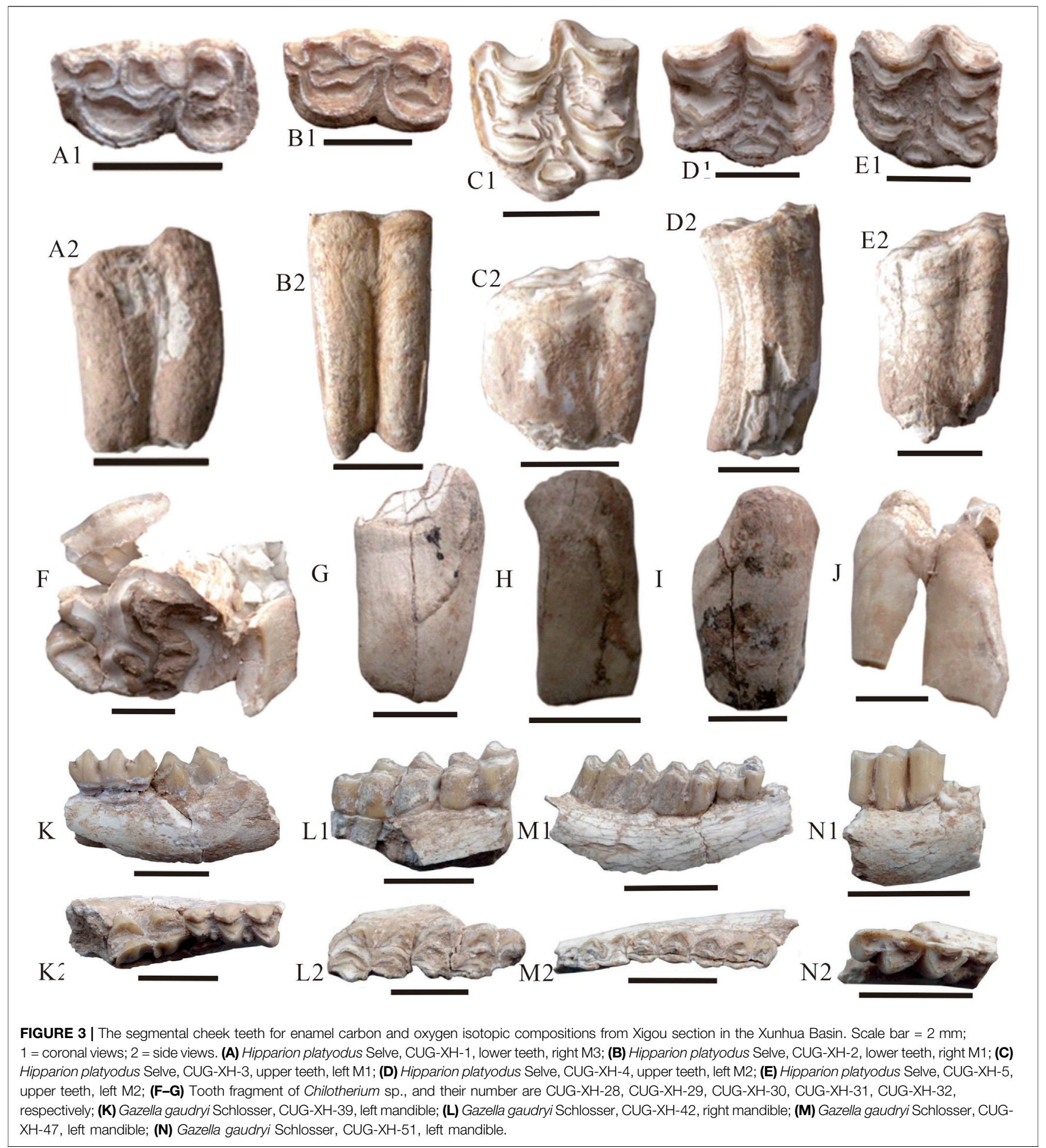

carbon and oxygen isotope ratios of the resulting $\mathrm{CO}_{2}$ were then analyzed using a Finnigan MAT Delta Plus XP stable isotope ratio mass spectrometer (IRMS) at the University of Rochester's SIREAL laboratory (Higgins and MacFadden, 2004). The analytical results are reported using the standard \%o notation where $\delta^{13} \mathrm{C}\left(\right.$ or $\left.\delta^{18} \mathrm{O}\right)=\left(\mathrm{R}_{\text {sample }} / \mathrm{R}_{\text {standard }}-1\right) \times 1,000$ and $\mathrm{R}_{\text {sample }}$ or $\mathrm{R}_{\text {standard }}$ is the ${ }^{13} \mathrm{C} /{ }^{12} \mathrm{C}\left(\right.$ or ${ }^{18} \mathrm{O} /{ }^{16} \mathrm{O}$ ) ratio of the sample or standard, respectively. Results are reported relative to the VPDB reference standard. Analytical precision for $\delta^{13} \mathrm{C}$ and $\delta^{18} \mathrm{O}$ was better than \pm 0.1 and $\pm 0.14 \%$, respectively. 


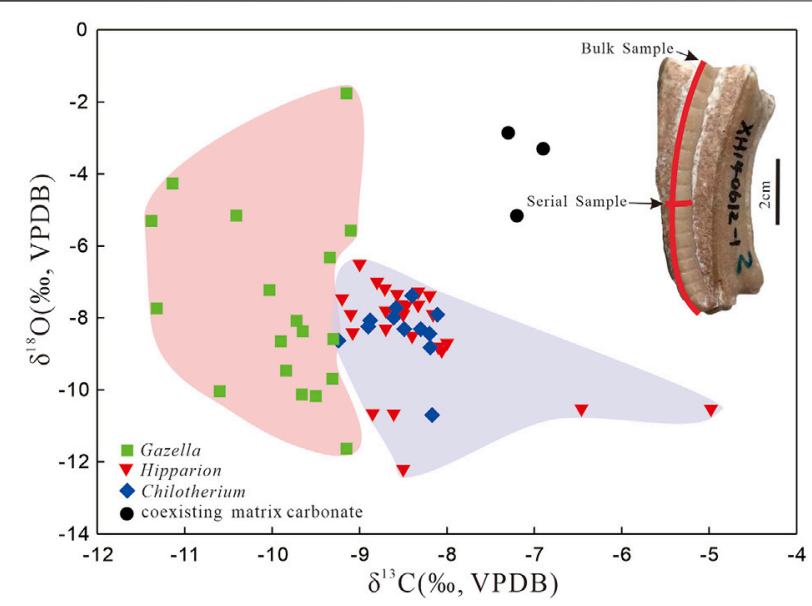

FIGURE $4 \mid \delta^{13} \mathrm{C}$ and $\delta^{18} \mathrm{O}$ in tooth enamel of Hipparion fauna (including Hipparion, Chilotherium, and Gazzela) and their coexisting matrix carbonates (Hough et al., 2011) in the Xunhua Basin.

\section{RESULTS AND INTERPRETATIONS}

The $\delta^{13} \mathrm{C}$ and $\delta^{18} \mathrm{O}$ of bulk enamel from 56 fossil teeth are reported in Figure 4 and Supplementary Table S1. Of the 56 teeth analyzed in this study, nine Hipparion teeth that were analyzed for bulk isotopes were serially sampled (Figure 5; Supplementary Table S2). There is no notable seasonal signal present in the carbon isotope data of the serial samples. The mean intra-tooth variation of enamel- $\delta{ }^{13} \mathrm{C}$ values in these nine teeth is $0.9 \pm 0.2 \%$. Sample XH- 8 has intra-tooth variation of just $0.5 \%$, the lowest value, and samples XH-5 and $\mathrm{XH}-13$ have intra-tooth variation of $1.2 \%$, the highest value. Intra-tooth variation is greater for $\delta^{18} \mathrm{O}$ (up to $4 \%$ ) than for $\delta^{13} \mathrm{C}$. Serial sampling of Hipparion reveals a strong seasonal signal in oxygen isotope data from the Xunhua Basin, indicating that the enamel samples, and thus the carbon isotope data, have not been strongly affected by diagenesis (Zin Maung Maung Thein et al., 2011). Moreover, comparison of the $\delta^{13} \mathrm{C}$ and $\delta^{18} \mathrm{O}$ values of the fossil tooth enamel with those of carbonates in the coexisting matrix

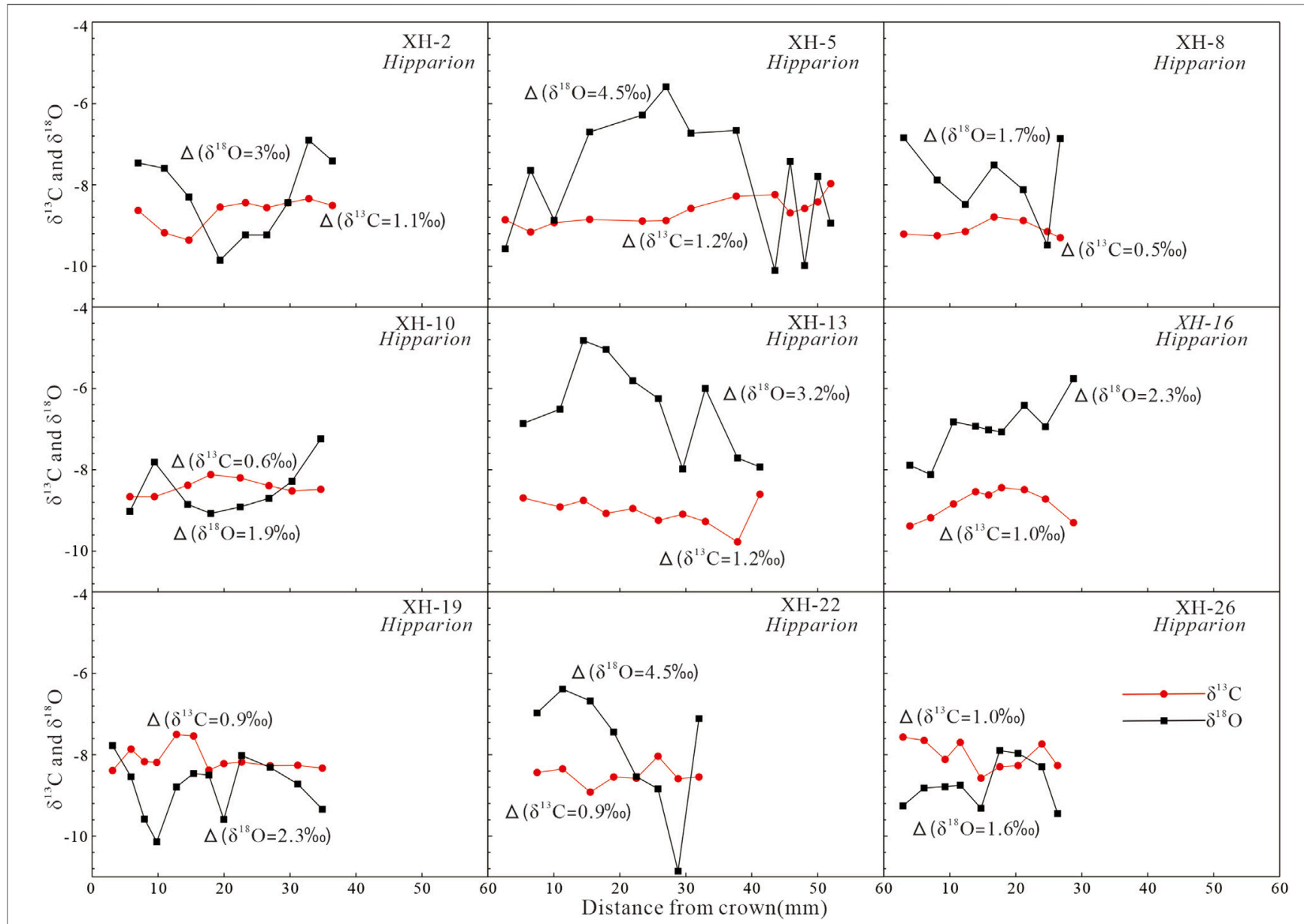

FIGURE 5 | Intra-tooth isotopic variations in selected Hipparion teeth from Xunhua Basin. $\Delta^{13} \mathrm{C}$ and $\Delta^{18} \mathrm{O}$ values indicate the range of carbon and oxygen isotopic variations, respectively, within each tooth. 


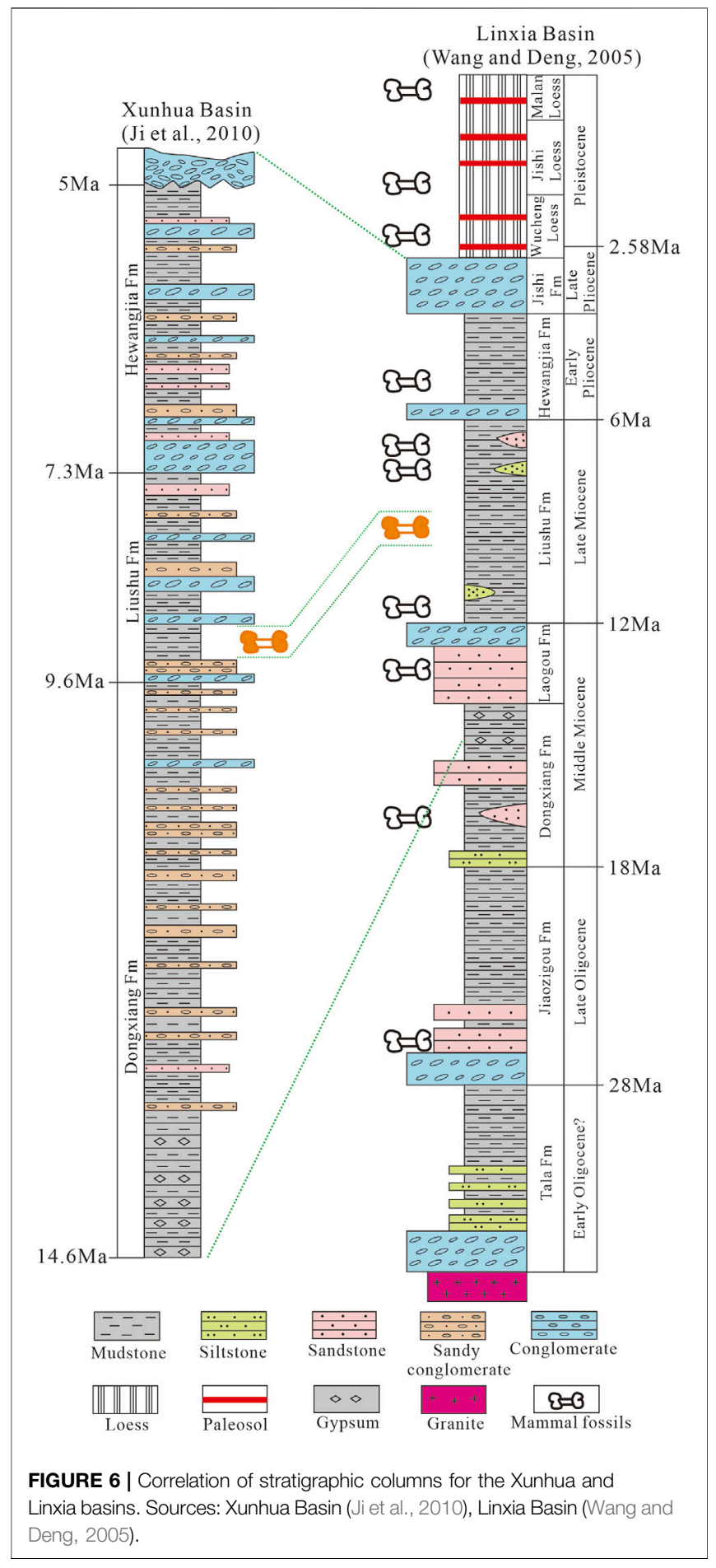

(Hough et al., 2011) provides a useful means of determining whether significant alteration of the original isotopic compositions of the enamel has occurred (Wang and Deng, 2005). A significant difference between the isotopic compositions of the enamel and matrix carbonates would argue against strong diagenetic alteration of the samples. Differences in $\delta^{13} \mathrm{C}$ and $\delta^{18} \mathrm{O}$ values between the analyzed fossil samples and their coexisting matrix carbonates $\left(\Delta^{13} \mathrm{C}_{\mathrm{e}-\mathrm{m}}\right.$ and $\left.\Delta^{18} \mathrm{O}_{\mathrm{e}-\mathrm{m}}\right)$ are plotted in Figure 4. The large $\Delta^{13} \mathrm{C}_{\mathrm{e}-\mathrm{m}}$ and $\Delta^{18} \mathrm{O}_{\mathrm{e}-\mathrm{m}}$ values are consistent with minimal or no diagenetic alteration of the tooth enamel of the Hipparion fauna in the Xunhua Basin.

Bulk enamel- $\delta{ }^{13} \mathrm{C}$ values range from -11.4 to $-5.0 \%$ with a mean of $-8.9 \pm 1.0 \%$ o $(n=56): 1)$ from -11.4 to $-9.1 \%$ with a mean of $-9.9 \pm 0.75 \%$ o $(n=18)$ for Gazella; 2$)$ from -9.2 to $-8.1 \%$ with a mean of $-8.5 \pm 0.35 \%$ o $(n=12)$ for Chilotherium; 3$)$ from -9.2 to $-5.0 \%$ with a mean of $-8.3 \pm 0.86 \%$ o $(n=26)$ for Hipparion. Only one fossil (Hipparion) has bulk $\delta^{13} \mathrm{C}$ values greater than $-6 \%$, a conservative cutoff for the presence of $\mathrm{C}_{4}$ plants in the diets of fossil mammals (Bowman et al., 2017). When comparing our results with data from Wang and Deng (2005) and Biasatti et al. (2010), Biasatti et al. (2018) (Figure 6), we found that the taxon-specific mean $\delta^{13} \mathrm{C}$ values in the Xunhua Basin tend to be slightly higher than those in the Linxia Basin (Figure 7). In addition, we found that fossil enamel $\delta^{13} \mathrm{C}$ was characterized by higher-amplitude variation in the Xunhua Basin than in the Linxia Basin (Figures 4, 7).

The fossils have bulk $\delta^{18} \mathrm{O}$ (VPDB) values of all tooth enamel ranging from $-12.2 \%$ o to $-1.8 \%$ with a mean of $-8.2 \pm 1.8 \%$ o $(n=56): 1)$ from -11.6 to $-1.8 \%$ with a mean of $-7.7 \pm 2.52 \%$ ( $n=18)$ for the Gazella; 2 ) from -10.7 to $-7.4 \%$ with a mean of $-8.4 \pm 0.83 \%$ o $(n=12)$ for the Chilotherium; 3$)$ from -12.2 to $-6.5 \%$ with a mean of $-8.4 \pm 1.4 \%$ o $(n=26)$ for the Hipparion. The $\delta^{18} \mathrm{O}$ of tooth enamel is similar for all specimens of all taxa, with the exception of a single Gazella that yielded a value $\sim 1.8 \%$ more positive than other specimens (Figure 4). This difference may be attributable to differences in dietary or drinking behavior between this Gazella specimen and the other fossils (Biasatti et al., 2010). A difference in dietary behavior is distinctly possible as Gazella usually ingest a large amount of water from leaves, and leaf water is strongly affected by relative humidity (Cormie et al., 1994; Koch, 1998). As a result, leaf $\delta^{18} \mathrm{O}$ values will increase with climatic aridity. Compared to the Linxia Basin, the mean $\delta^{18} \mathrm{O}$ values of fossil enamel in the Xunhua Basin are higher (by $\sim 3.4 \%$ o) and the most negative $\delta^{18} \mathrm{O}$ values in the Xunhua Basin is lower than that in the Linxia Basin (Figure 7).

\section{DISCUSSION}

\section{Diets and Habitats of Hipparion Fauna in the Xunhua Basin at $\sim 9 \mathrm{Ma}$}

The carbon isotopic composition of mammal teeth closely follows an animal's diet, reflecting consumption of two types of vegetation with differing isotopic signatures: $C_{3}$ plants (i.e., trees, most shrubs, and cool-season grasses) with $\delta^{13} \mathrm{C}$ values of -34 to $-23 \%$ (VPDB; mean $-27 \%$ ) and $\mathrm{C}_{4}$ plants (i.e., warm-season grasses) with $\delta^{13} \mathrm{C}$ values of -17 to $-9 \%$ (mean -13\%o) (Quade et al., 1992). These differences in carbon isotopic composition are due to use of different photosynthetic pathways: the Calvin-Benson cycle for $\mathrm{C}_{3}$ plants versus the Hatch-Slack cycle for $\mathrm{C}_{4}$ plants. Mammal teeth are enriched in the heavy carbon isotope $\left({ }^{13} \mathrm{C}\right)$ by $\sim 14 \%$ relative to their dietary source (Cerling and Harris, 1999), based on which enamel $\delta^{13} \mathrm{C}$ values of $<-9 \%$ and $>-2 \%$ indicate a pure $\mathrm{C}_{3}$ diet and a pure $\mathrm{C}_{4}$ diet, respectively, with mixed feeders 


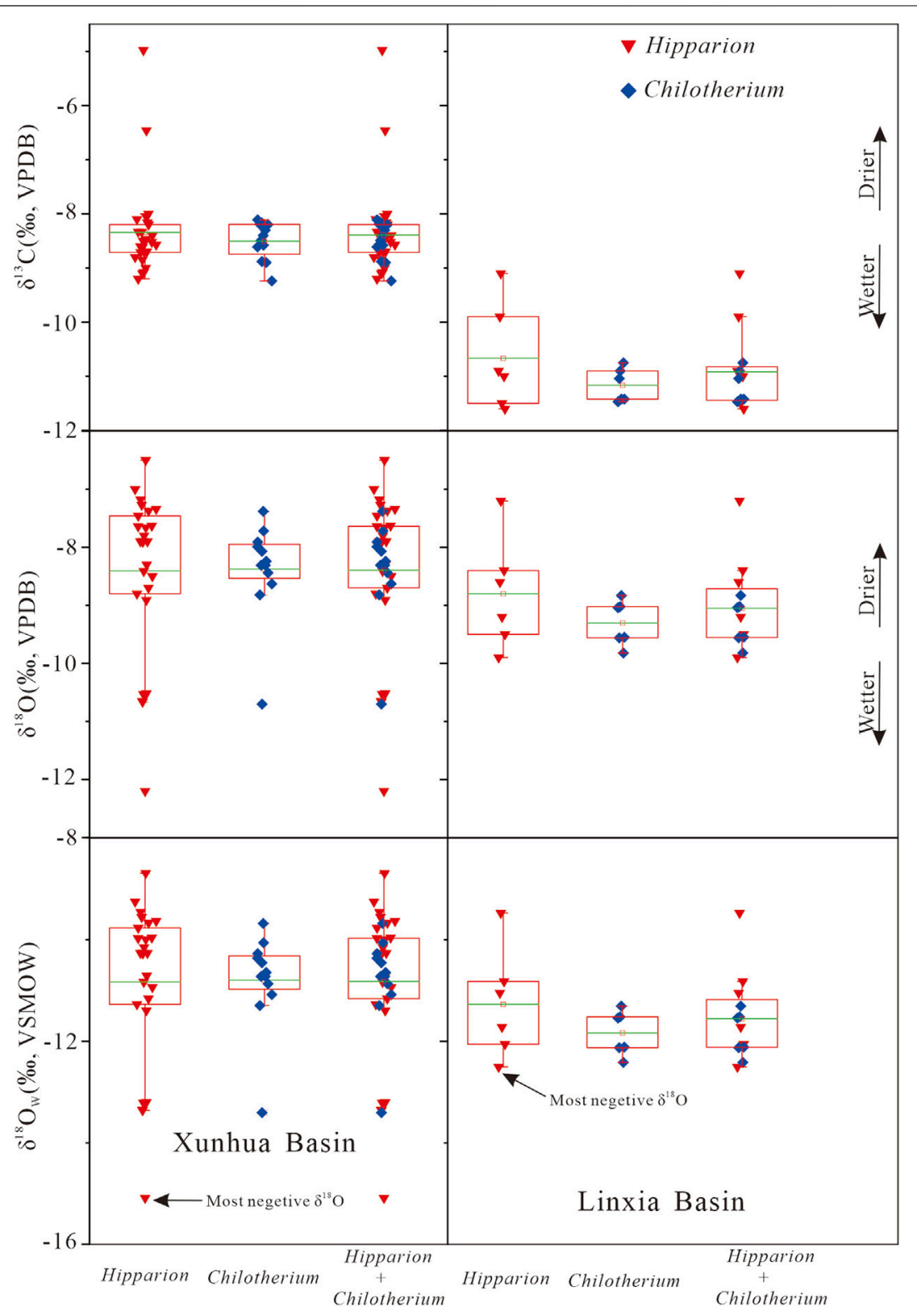

FIGURE 7 |Comparison of enamel $\delta^{13} \mathrm{C}, \delta^{18} \mathrm{O}$ and the estimated $\delta^{18} \mathrm{O}_{w}$ values of obligate drinkers (Hipparion and Chilotherium) of Xunhua Basin at $\sim 9$ Ma and the Linxia Basin at 9.5 to 9 Ma (Wang and Deng, 2005; Biasatti et al., 2010, 2018).

yielding intermediate values (Lee-Thorp and van der Merwe, 1987; Koch, 1998; Cerling and Harris, 1999; Koch and Cerling, 2002; Passey et al., 2002). However, in arid and semi-arid (i.e., water-stressed) environments, a maximum enamel- $\delta^{13} \mathrm{C}$ value for a pure $\mathrm{C}_{3}$ diet could be as high as $-8 \%$ o for modern herbivores and $-6 \%$ for fossil herbivores due to changes in the $\delta^{13} \mathrm{C}$ value of atmospheric $\mathrm{CO}_{2}$ (Bowman et al., 2017). In closed environments such as forests, $\delta^{13} \mathrm{C}$ values are systematically lower due to the influence of soil respiration and low irradiance (Schleser and Jayasekera, 1985; van der Merwe and Medina, 1989).

The mean $\delta^{13} \mathrm{C}$ value of enamel samples of the $\sim 9-\mathrm{Ma}$ Hipparion fauna from the Xunhua Basin is $-8.9 \pm 1.0 \%$ $\left(n=56\right.$, Figure 4). The $\delta^{13} \mathrm{C}$ of atmospheric $\mathrm{CO}_{2}$ in the Late Miocene was approximately $-6.4 \%$ (Tipple et al., 2010), which is higher than the current value of $-8.2 \%$ (Cuntz, 2011). After correction for secular variation in the $\delta^{13} \mathrm{C}$ of atmospheric $\mathrm{CO}_{2}$ $(1.8 \%$ ) and biochemical fractionation between diet and enamel $(\sim 14 \%)$, the dietary $\delta^{13} \mathrm{C}$ of the Hipparion fauna ranged from -27.2 to $-20.8 \%$ o (mean $-24.7 \pm 1.0 \%$ ), with the highest value found in a Hipparion specimen and the lowest in a Gazella. These values are consistent with a diet consisting mainly of $\mathrm{C}_{3}$ plants. Further proof of a lack of ingestion of $\mathrm{C}_{4}$ plants in this ecosystem comes from the serial enamel- $\delta^{13} \mathrm{C}$ data from individual teeth, which show little or no intra-tooth carbon isotopic variation (Figure 5). However, one Hipparion tooth yielded a relatively 
high dietary $-\delta^{13} \mathrm{C}$ value (-20.8\%o), suggesting the presence of a small amount of $\mathrm{C}_{4}$ plants in the local ecosystem. Thus, the Hipparion fauna in the Xunhua Basin at $\sim 9$ Ma fed mostly on $\mathrm{C}_{3}$ plants, even though the local ecosystem is likely to have contained some $\mathrm{C}_{4}$ grasses, which is consistent with previous observations that $\mathrm{C}_{4}$ plants were already present on the Tibetan Plateau and the Chinese Loess Plateau at 9-8 Ma (Morgan et al., 1994; Zhang et al., 2009, Zhang et al., 2012b).

Variation of dietary- $\delta{ }^{13} \mathrm{C}$ values among taxa likely reflects differences in the herbivores' habitats and eating behaviors (Figure 4). Gazella has the lowest $\delta^{13} \mathrm{C}$ values (range -27.2 to $-24.9 \%$, mean $25.7 \pm 0.75 \%$ ), suggesting that they had pure $\mathrm{C}_{3}$ diets and preferred forest habitats. In contrast, higher dietary$\delta^{13} \mathrm{C}$ values are recorded by Hipparion (range -25.0 to $-20.8 \%$, mean $-24.1 \pm 0.86 \%$ ) and Chilotherium ( -25.0 to $-23.9 \%$, mean $-24.3 \pm 0.35 \%$ ). These values are indicative of feeding mainly on $\mathrm{C}_{3}$ plants growing in more open environments, although some Hipparion specimens may have consumed a certain amount of $\mathrm{C}_{4}$ plants. The composition of the Hipparion fauna in the Xunhua Basin reflects an herbivore community adapted to both forest and grassland habitats. Gazella gaudryi Schlosser and Cervocerus sp. represent forest phenotypes, whereas Hipparion platyodus Selve, Chilotherium sp. and Gazella dorcadoides had high-crown teeth and were representative of grassland taxa (Zhang et al., 2002). Moreover, palynological data reveal that the Xunhua Basin contained mainly shrubs and herbs (e.g., Chenopodiaceae, Ephedra and Gramineae), broadleaved trees, and conifers at 12.5-8 Ma (Xu et al., 2015). Combined with enamel- $\delta^{13} \mathrm{C}$ data, the presence of the Hipparion fauna in the Xunhua Basin at $\sim 9 \mathrm{Ma}$ is indicative of a mixed forest-grassland setting.

\section{$\delta^{18} \mathrm{O}$ of Meteoric Water and its Paleoclimatic Implications}

Oxygen isotopes in mammal tooth enamel contain valuable information about climatic conditions (Kohn and Cerling, 2002; Wang et al., 2008b; Wang et al., 2013). The $\delta^{18} \mathrm{O}$ values of tooth enamel can reflect the isotopic constitution of local meteoric water, which is strongly correlated with local climate conditions, especially for obligate drinkers $(>100 \mathrm{~kg}$ ) that obtain most of their water from meteoric sources (Longinelli, 1984; Luz et al., 1984; Bryant and Froelich, 1995; Wang et al., 2008a). Precipitation is known to display large intra-annual $\delta^{18} \mathrm{O}$ variations in response to climatic seasonality. Rivers and lakes exhibit a much smaller $\delta^{18} \mathrm{O}$ range than precipitation as their water is mostly derived from groundwater that integrates precipitation spatially and temporally across a watershed (Clark and Fritz, 1997). Precipitation isotope data from IAEA-GNIP (International Atomic Energy Agency Global Network for Isotopes in Precipitation) stations in the study area show that summer precipitation is more depleted in ${ }^{18} \mathrm{O}$ than winter precipitation (Stacklyn et al., 2017; IAEA/WMO, 2018; Sun et al., 2019). This pattern is characteristic of the Asian Summer Monsoon regime (Johnson and Ingram, 2004). The weighted annual mean $\delta^{18} \mathrm{O}$ of precipitation in this region shows a decreasing trend with distance from the ocean (the moisture source): $-5.8 \pm 1.1 \%$ at Guangzhou, $-6.2 \pm 0.9 \%$ at Guilin, $-6.5 \pm 0.7 \%$ at Liuzhou, $-6.4 \pm 2.1 \%$ at
Wuhan, and $-7.0 \pm 1.1 \%$ at Chengdu (Stacklyn et al., 2017; IAEA/ WMO, 2018; Sun et al., 2019), which reflects a combination of the "continental effect" and the "latitude effect" (Dansgaard, 1964). In summer months, moisture was carried by the Asian summer monsoon from the ocean inland, increasing precipitation over the continent. Because heavy isotopes are preferentially removed from vapor by condensation, the remaining vapor in an air mass and the precipitation subsequently produced from it become progressively more depleted in the heavy isotope $\left({ }^{18} \mathrm{O}\right)$ as air masses move further inland and more vapor condenses to precipitation (Dansgaard, 1964). In a given area, the higher the precipitation amount, the lower the $\delta^{18} \mathrm{O}$ value, owing to the "amount effect" (Dansgaard, 1964). At mid to high latitudes, there is a strong positive correlation $\left(0.58 \%{ }^{\circ} \mathrm{C}\right)$ between precipitation $\delta^{18} \mathrm{O}$ and surface air temperature (Dansgaard, 1964), the so-called "temperature effect", but this correlation does not apply to the Asian monsoon region or to low-latitude regions in general (Sun et al., 2019).

The $\delta^{18} \mathrm{O}$ values of structural carbonate in the fossil enamel samples from the Xunhua Basin range from -12.2 to $-1.8 \%$ (mean $-8.2 \pm 1.8 \% ; n=56$ ). The majority of specimens were large mammals (e.g., Hipparion, Chilotherium) that were presumably obligate drinkers. The $\delta^{18} \mathrm{O}$ values of enamel range from -12.2 to $-6.5 \%$ (mean $-8.4 \pm 1.4 \%$ ) for Hipparion and from -10.7 to $-7.4 \%$ o (mean $-8.4 \pm 0.83 \%$ ) for Chilotherium. The similar $\delta^{18} \mathrm{O}$ values of Hipparion and Chilotherium indicate that they may have had a similar water source. Half of the Hipparion teeth shows limited $\delta^{18} \mathrm{O}$ variation (range -2.3 to $-1.6 \%$, Figure 5), which likely indicates that these animals drank from isotopically buffered water sources such as rivers or lakes (Clark and Fritz, 1997). The other half displays relatively large intra-tooth variations (up to $4.5 \%$, Figure 5), possibly reflecting large seasonal variation in the $\delta^{18} \mathrm{O}$ of ingested water. Enamel samples from fossil Gazella were generally enriched in ${ }^{18} \mathrm{O}$ with a wide range of $\delta^{18} \mathrm{O}$ values compared to other taxa (Figure 4), implying that Gazella migrated between forested and relatively open habitats and consumed leaf water or highly evaporated lake/pond water (Sun et al., 2021).

Previous studies have shown that the enamel- $\delta^{18} \mathrm{O}$ values of obligate drinkers are strongly correlated with the $\delta^{18} \mathrm{O}_{w}$ of local meteoric water (Kohn and Cerling, 2002; Levin et al., 2006; Wang et al., 2012). Applying the enamel-water $\delta^{18} \mathrm{O}$ relation for obligate drinkers given in Kohn and Cerling (2002), i.e., $\delta^{18} \mathrm{O}_{\text {enamle-CO3 }}=$ $0.9 \times \delta^{18} \mathrm{O}_{\text {water }}+1.245$, to enamel samples of Hipparion and Chilotherium from the Xunhua Basin yields a mean paleometeoric water $\delta^{18} \mathrm{O}_{w}$ value of $-10.8 \pm 1.38 \%$ (VSMOW, $n=$ 38 ). However, the mean enamel- $\delta^{18} \mathrm{O}$ value may overestimate paleo-meteoric water $\delta^{18} \mathrm{O}_{w}$ due to subsequent evaporation induced $\delta^{18} \mathrm{O}$ enrichment. The best estimate of paleo-meteoric water $\delta^{18} \mathrm{O}_{w}$ is based on the lowest measured enamel- $\delta^{18} \mathrm{O}$ value $(-12.2 \%)$, which yields a paleo-meteoric water estimate of $-15.1 \%$. Limited data from the modern Xunhua Basin yield a mean $\delta^{18} \mathrm{O}_{w}$ of $\sim-6.5 \%$ (Hough et al., 2011), which is $8.6 \%$ higher than the estimated paleo-meteoric water value of $-15.1 \%$ at $\sim 9 \mathrm{Ma}$. The present-day Xunhua Basin is within the Asian monsoon region (Figure 8), with climate mainly controlled by the East Asian Summer Monsoon. In summer monsoon regions, 


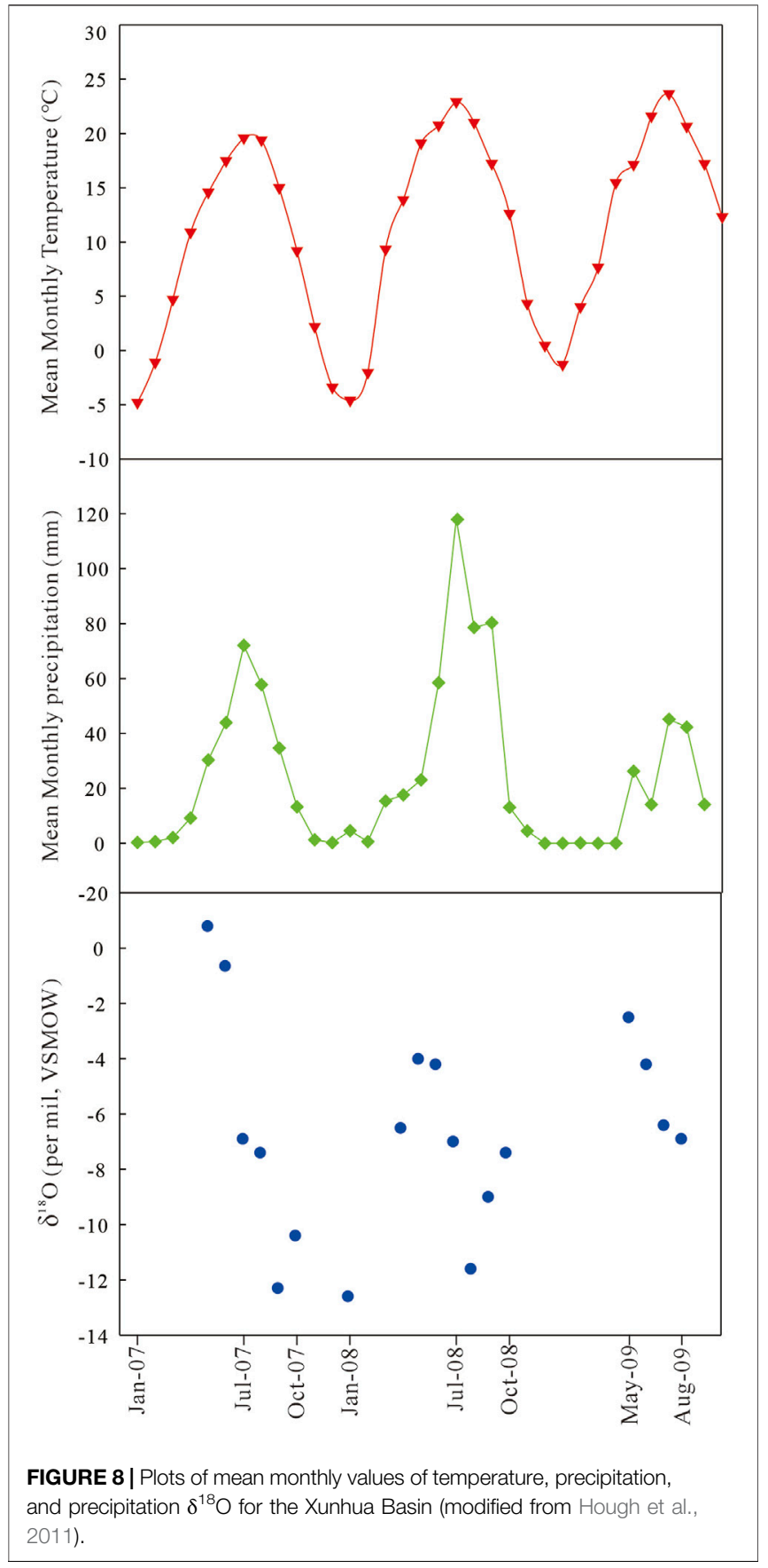

summer precipitation has lower $\delta^{18} \mathrm{O}$ than winter precipitation (Figure 8), primarily due to the "amount effect" (Dansgaard, 1964). The amount of precipitation is mainly controlled by monsoonal intensity (Li et al., 2020). Thus, the lower reconstructed paleo-meteoric water $\delta^{18} \mathrm{O}$ values at $\sim 9 \mathrm{Ma}$ are consistent with a wetter climate and possibly stronger influence of the East Asian Monsoon than today. This inference is supported by clay mineralogy and chemical weathering indices, which indicate a relatively warmer and more humid environment in the Xunhua Basin between $12.5 \mathrm{Ma}$ and $8 \mathrm{Ma}$ (Wang et al., 2010; Ye et al., 2010).

\section{Comparison With Contemporaneous Linxia Basin Fauna}

A large number of isotopic paleodiet records from the Upper Miocene of China have been published, yielding data for the Gyirong Basin (Wang et al., 2006; Wang et al., 2012), Zhada Basin (Wang et al., 2013), Kunlun Pass Basin (Wang et al., 2008b), Qaidam Basin (Zhang et al., 2012a), Linxia Basin (Wang and Deng, 2005; Biasatti et al., 2010; Biasatti et al., 2018), Fugu Area (Li et al., 2020), and Yushe Basin (Ciner et al., 2015). These well-dated records from various locations provide a basis for conducting a regional comparison of paleoclimatic changes on the northeastern Tibetan Plateau. The Linxia Basin is close to the Xunhua Basin, separated by the Jishi Shan and located only $50 \mathrm{~km}$ to the east. The Upper Miocene strata of the Linxia Basin contain abundant, diverse, and well-preserved mammalian fossils (Figure 6). Here, we chose a nearly contemporaneous Hipparion fauna (including Hipparion and Chilotherium) of the Linxia Basin with an age of $29.5-9.0 \mathrm{Ma}$, that was deposited in mudstones, to compare with the $\delta^{13} \mathrm{C}$ and $\delta^{18} \mathrm{O}$ records of the Xunhua Basin at $\sim 9 \mathrm{Ma}$ (Figures 6, 7).

The bulk enamel $\delta^{13} \mathrm{C}$ of Hipparion and Chilotherium from the Xunhua Basin ranges from -9.2 to $-5.0 \%$ (mean $-8.4 \pm 0.74 \%$ ), and that of the Linxia Basin ranges from -11.6 to $-9.1 \%$ o (mean $-10.9 \pm$ 0.74\%o) (Wang and Deng, 2005; Biasatti et al., 2010; Biasatti et al., 2018). The difference in mean $\delta^{13} \mathrm{C}$ values between the Xunhua and Linxia basins is significant ( $p<0.00001$; t-test) (Figure 6). Kohn (2010) demonstrated that the $\delta^{13} \mathrm{C}$ values of modern $\mathrm{C}_{3}$ plants are negatively corelated with mean annual precipitation (MAP). The regression equation is: $\delta^{13} \mathrm{C}=-10.29+1.9 \times 10^{-4}$ $\times$ Altitude $-5.61 \times \log _{10}(\mathrm{MAP}+300)-0.0124 \times \mathrm{Abs}$ (Latitude), where units are $\mathrm{m}$ for Altitude and $\mathrm{mm} / \mathrm{yr}$ for MAP, and the relationship yields $\mathrm{r}^{2}=0.59$. The Xunhua and Linxia basins have average elevations of $2,200 \mathrm{~m}$ and $1917 \mathrm{~m}$, respectively. The difference of $\sim 2.5 \%$ in mammal enamel $\delta^{13} \mathrm{C}$ values between these basins (Wang and Deng, 2005; Biasatti et al., 2010; Biasatti et al., 2018) is equivalent to a $\sim 300 \mathrm{~mm}$ increase in MAP in the Linxia Basin relative to the Xunhua Basin. This suggests that the Hipparion fauna in the Xunhua Basin may have experienced a drier climate than the Linxia Basin fauna, which is also supported by our oxygen isotope results. $\delta^{18} \mathrm{O}$ values of Hipparion and Chilotherium from the Xunhua Basin (mean $-8.4 \pm$ $1.2 \%$, range -12.2 to $-6.5 \%$ ) are somewhat higher than those from the Linxia Basin (mean $-9.1 \pm 0.75 \%$, range -9.9 to $-7.2 \%$ ) ( $p=0.08$; t-test) (Wang and Deng, 2005; Biasatti et al., 2010; Biasatti et al., 2018), reflecting greater aridity in the former basin (Dettman et al., 2003; Wang and Deng, 2005; Hough et al., 2011).

The primary factors controlling Late Miocene aridification in the Xunhua and Linxia basins were global cooling (Miao et al., 2011) and tectonic uplift of the Tibetan Plateau (Zhisheng et al., 2001; Zhang et al., 2012b; Yang et al., 2021). Many studies have inferred that increasing aridification of the northeastern Tibetan Plateau after $14 \mathrm{Ma}$ was the result of global climatic cooling (Zachos et al., 2001; Ma et al., 2005; Jiang and Ding, 2008; Miao et al., 2011; Xu et al., 2015). Global cooling is likely to have reduced the amount of water vapor in the atmosphere, weakening precession-related moisture cycles (Zachos et al., 2001). Palynological studies in the Jiuxi Basin, 


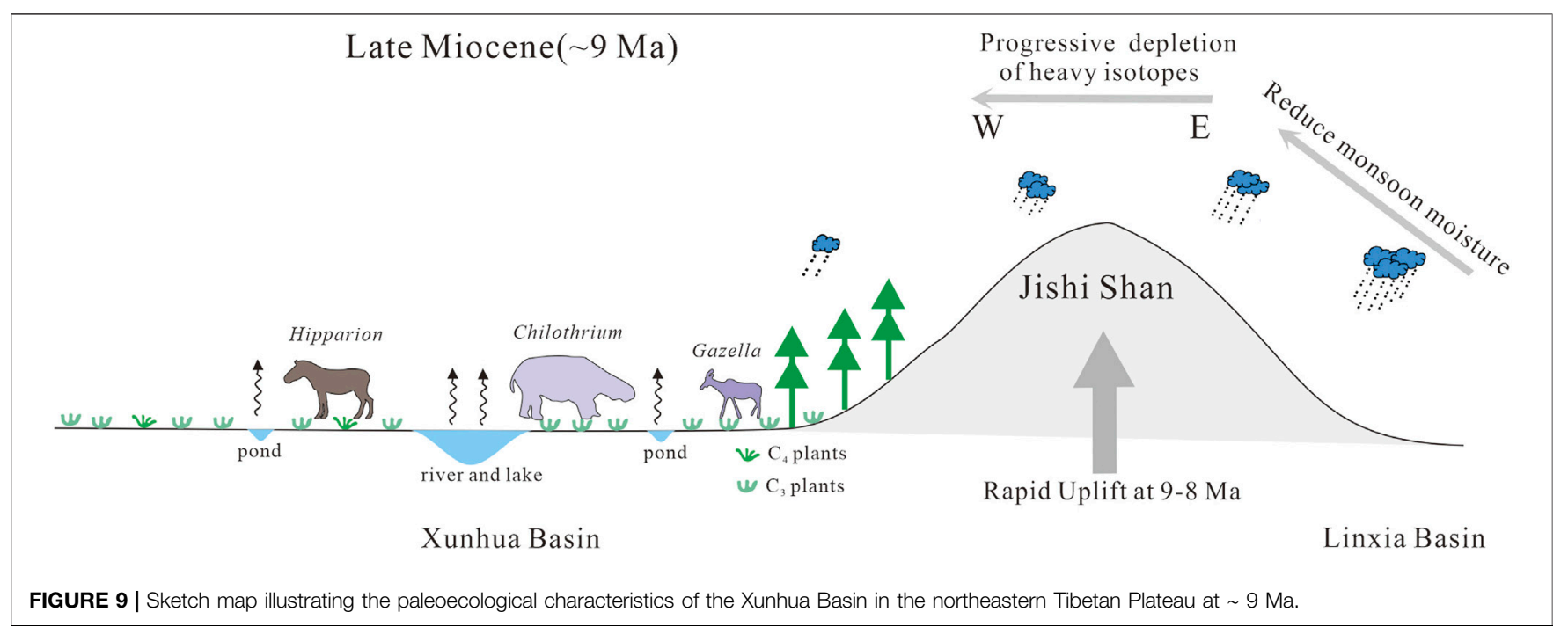

Qaidam Basin and Guyuan area indicate a long-lasting cooling trend beginning at $\sim 13-12 \mathrm{Ma}$ (Ma et al., 2005; Jiang and Ding, 2008; Miao et al., 2011). Sporopollen and geochemical records of paleoclimate in the Xunhua Basin demonstrate a gradual cooling and drying trend from $\sim 14 \mathrm{Ma}$ to $5 \mathrm{Ma}$ (Xu et al., 2015). However, differences in calculated $\delta^{18} \mathrm{O}_{\mathrm{w}}$ between the Xunhua and Linxia basins, despite their proximity (Figure 6), suggest that global cooling was not the sole, or even the dominant, control on climate change on the northeastern Tibetan Plateau at $\sim 9 \mathrm{Ma}$.

Many lines of evidence confirm that the northeastern Tibetan Plateau experienced strong tectonic activity during the Middle-Late Miocene (Molnar, 2005; Lease et al., 2007; Lin et al., 2010; Lease et al., 2011; Yuan et al., 2011; Lease et al., 2012; Yuan et al., 2013; Fang et al., 2016; Fu et al., 2017; Yang et al., 2017; Saylor et al., 2018). For example, Yuan et al. (2011) inferred initiation of the Ela Shan and Riyue Shan strike-slip faults at $9 \pm 1$ and $10 \pm 3 \mathrm{Ma}$, respectively, based on estimated Quaternary slip rates of $\sim 1.1 \mathrm{~mm} / \mathrm{yr}$ and $\sim 10 \mathrm{~km}$ offset of older geologic contracts. The Laji Shan was first uplifted at 24-22 Ma and underwent accelerated uplift at 14-8 Ma, as indicated by recent studies of paleomagnetism and sedimentary facies of similar deposits in the Xunhua Basin and low-temperature thermochronometry of the Laji Shan (Lease et al., 2011, 2012). The Jishi Shan first began to rise at $13 \mathrm{Ma}$ (Hough et al., 2011; Lease et al., 2011; Saylor et al., 2018), likely reflecting a reorientation of contractile deformation from NNE-SSW to ENEWSW on the northeastern Tibetan Plateau at that time (Lease et al., 2011; Yuan et al., 2013), followed by intense uplift at 9-8 Ma (Lease et al., 2007; Saylor et al., 2018). Magnetostratigraphic correlations and stratigraphic architectures constrained uplift of the Liupan Shan beginning at $9.5 \mathrm{Ma}$, followed by rapid cooling at $8.2-7.3 \mathrm{Ma}$ as recorded by apatite fission track data (Lin et al., 2010). Moreover, rapid uplift at $9-8 \mathrm{Ma}$ is also evidenced by thick conglomerate layers and increased sedimentation rates in the Mojiazhuang section of the Xining Basin, the Heilingding section of the Linxia Basin, the Xigou section of the Xunhua Basin, and the
Jiarang section of the Jianzha Basin (Ji et al., 2010; Fang et al., 2016; Fu et al., 2017; Yang et al., 2017).

Uplift of the Tibetan Plateau had profound effects on local, regional and global climate (Raymo and Ruddiman, 1992; Zhisheng et al., 2001). Based on the regional records of silicate weathering intensity, the Linxia and Xining basins experienced divergent climatic patterns marked by a decrease in $(\mathrm{I} / \mathrm{S}+$ smectite $) /($ illite + chlorite $)$ ratios and overall lower values of chemical weathering proxies in the Xining Basin relative to the Linxia Basin, reflecting a drier climate in the former basin since $\sim 8 \mathrm{Ma}$ due to uplift of the surrounding mountains (Yang et al., 2021). This scenario may apply also to the Xunhua and Linxia basins. The Linxia Basin opens eastward onto the western margin of the Chinese Loess Plateau, allowing monsoonal moisture penetration (Figure 1). The Xunhua Basin is located to the west of the Linxia Basin, separated from it by the Jishi Shan, whose peaks reach 3,500 $\mathrm{m}$ (Figure 1). It is thus located in an orographic rainshadow, and as the Jishi Shan rose higher during the Late Miocene (at 9-8 Ma; Lease et al., 2007; Saylor et al., 2018), the Xunhua Basin underwent greater aridification than the Linxia Basin (Figure 9).

The estimated isotopic composition of meteoric water $\left(\delta^{18} \mathrm{O}_{\mathrm{w}}\right)$ in the Xunhua Basin $(-15.1 \%$ ) is based on the lowest measured value of enamel- $\delta^{18} \mathrm{O}$, which confirms that fossils yielding higher enamel- $\delta^{18} \mathrm{O}$ values in the Xunhua Basin were influenced by more-evaporated surface waters. This value is $\sim 3 \%$ more negative than the $\delta^{18} \mathrm{O}_{\mathrm{w}}$ estimate for the Linxia Basin $(-12.1 \%)$, which is consistent with the aforementioned orographic rainshadow effect, that is, the precipitation across the mountain ranges will be more isotopically depleted. Strong aridification led to intense evaporation within the Xunhua Basin, causing enrichment of surface waters in the heavy isotope of oxygen. This process resulted in higher mean enamel- $\delta^{18} \mathrm{O}$ of the Xunhua Basin $(-8.4 \pm 1.2 \%$ ) relative to the Linxia Basin $(-9.1 \pm 0.75 \%$ o) 


\section{CONCLUSION}

Upper Miocene sediments in the Xunhua Basin of the northeastern Tibetan Plateau yielded a variety of mammal fossils dating to $\sim 9 \mathrm{Ma}$, including Hipparion platyodus Selve, Chilotherium sp., Gazella gaudryi Schlosser, Gazella paotehensis, Gazella dorcadoides, Gazella sp., and Cervocerus sp. Stable carbon and oxygen isotope compositions of the fossil tooth enamel allowed significant inferences regarding the paleoenvironment of the Xunhua Basin at $\sim 9 \mathrm{Ma}$. First, enamel $\delta^{13} \mathrm{C}$ data indicate that the Hipparion fauna mostly fed on $\mathrm{C}_{3}$ plants even though the local ecosystem contained a certain amount of $\mathrm{C}_{4}$ grasses. Integrated with pollen records, we infer that the Xunhua Basin at $\sim 9 \mathrm{Ma}$ contained a mixed forest-grassland ecosystem. Second, the influence of the Asian Summer Monsoon was stronger at $\sim 9 \mathrm{Ma}$ than today, as reflected by paleo-meteoric water $\delta^{18} \mathrm{O}$ (as reconstructed from minimum fossil enamel $\delta^{18} \mathrm{O}$ ) lower than that of modern precipitation in the region. Third, higher $\delta^{13} \mathrm{C}$ and $\delta^{18} \mathrm{O}$ values for fossil tooth enamel from the Xunhua Basin relative to contemporaneous fossils in the neighboring Linxia Basin indicate a relatively drier climate in the former basin, which can be attributed to development of an orogenic rainshadow following uplift of the Jishi Shan.

\section{DATA AVAILABILITY STATEMENT}

The original contributions presented in the study are included in the article/Supplementary Material, further inquiries can be directed to the corresponding authors.

\section{REFERENCES}

Ayliffe, L. K., Chivas, A. R., and Leakey, M. G. (1994). The Retention of Primary Oxygen Isotope Compositions of Fossil Elephant Skeletal Phosphate. Geochimica et Cosmochimica Acta. 58 (23), 5291-5298. doi:10.1016/0016-7037(94)90312-3

Biasatti, D., Wang, Y., and Deng, T. (2010). Strengthening of the East Asian Summer Monsoon Revealed by a Shift in Seasonal Patterns in Diet and Climate after 2-3Ma in Northwest China. Palaeogeogr. Palaeoclimatol. Palaeoecol. 297, 12-25. doi:10.1016/j.palaeo.2010.07.005

Biasatti, D., Wang, Y., and Deng, T. (2018). Paleoecology of Cenozoic Rhinos From Northwest China: a Stable Isotope Perspective. Vertebrata Palasiatica. 56 (1), 45-68. doi:10.19615/j.cnki.1000-3118.10519

Biasatti, D., Wang, Y., Gao, F., Xu, Y., and Flynn, L. (2012). Paleoecologies and Paleoclimates of Late Cenozoic Mammals from Southwest China: Evidence From Stable Carbon and Oxygen Isotopes. J. Asian Earth Sci. 44, 48-61. doi:10.1016/j.jseaes.2011.04.013

Bowman, C. N., Wang, Y., Wang, X., Takeuchi, G. T., Faull, M., Whistler, D. P., et al. (2017). Pieces of the Puzzle: Lack of Significant C4 in the Late Miocene of Southern California. Palaeogeogr. Palaeoclimatol. Palaeoecol. 475, 70-79. doi:10.1016/j.palaeo.2017.03.008

Bryant, D., and Froelich, P. (1995). A Model of Oxygen Isotope Fractionation in Body Water of Large Mammals. Geochim. Cosmochim. Acta. 59, 4523-4537. doi:10.1016/0016-7037(95)00250-4

Bryant, J. D., Froelich, P. N., Showers, W. J., and Genna, B. J. (1996). Biologic and Climatic Signals in the Oxygen Isotopic Composition of Eocene-Oligocene Equid Enamel Phosphate. Palaeogeogr. Palaeoclimatol. Palaeoecol. 126, 75-89. doi:10.1016/S0031-0182(96)00071-5

\section{AUTHOR CONTRIBUTIONS}

The idea was provided by the corresponding author KZ. First author FH conducted the experiment and wrote the manuscript. Corresponding author BS guided the work and modified this paper. YS and WH gave much advice for this manuscript. TA provided technical input and assistance with English. ML and QL collected the fossils in the field. JJ offered correct age of the Xigou section.

\section{FUNDING}

This work was supported by the National Natural Science Foundation of China (Grant Nos. 42072141, 41772107) and the China Geological Survey (No. DD20190370).

\section{ACKNOWLEDGMENTS}

We are very grateful to Xiaohu Kou, Fenning Chen, Fang Han, Jianyu Zhang for field assistance in the Xunhua Basin, Higgins Penny for experimental assistance and Chaowen Wang, Ke Yin and Zhao Liu for their valuable suggestions. We greatly thank the editor and reviewers for their careful work and constructive suggestions to this paper.

\section{SUPPLEMENTARY MATERIAL}

The Supplementary Material for this article can be found online at: https://www.frontiersin.org/articles/10.3389/feart.2021.717720/ full\#supplementary-material

Cerling, T. E., Harris, J. M., Ambrose, S. H., Leakey, M. G., and Solounias, N. (1997). Dietary and Environmental Reconstruction with Stable Isotope Analyses of Herbivore Tooth Enamel from the Miocene Locality of Fort Ternan, Kenya. J. Hum. Evol. 33, 635-650. doi:10.1006/jhev.1997.0151

Cerling, T. E., and Harris, J. M. (1999). Carbon Isotope Fractionation Between Diet and Bioapatite in Ungulate Mammals and Implications for Ecological and Paleoecological Studies. Oecologia. 120, 347-363. doi:10.1007/s004420050868

Cerling, T. E., Wang, Y., and Quade, J. (1993). Expansion of C4 Ecosystems as an Indicator of Global Ecological Change in the Late Miocene. Nature. 361, 344-345. doi:10.1038/361344a0

Ciner, B., Wang, Y., Deng, T., Flynn, L., Hou, S., and Wu, W. (2015). Stable Carbon and Oxygen Isotopic Evidence for Late Cenozoic Environmental Change in Northern China. Palaeogeogr. Palaeoclimatol. Palaeoecol. 440, 750-762. doi:10.1016/j.palaeo.2015.10.009

Clark, I. D., and Fritz, P. (1997). Environmental Isotopes in Hydrology. Boca Raton: CRC Press.

Cormie, A. B., Luz, B., and Schwarcz, H. P. (1994). Relationship Between the Hydrogen and Oxygen Isotopes of Deer Bone and Their Use in the Estimation of Relative Humidity. Geochimica et Cosmochimica Acta. 58, 3439-3449. doi:10.1016/0016-7037(94)90097-3

Cuntz, M. (2011). A Dent in Carbon's Gold Standard. Nature. 477, 547-548. doi:10.1038/477547a

Dansgaard, W. (1964). Stable Isotopes in Precipitation. Tellus. 16, 436-468. doi:10.3402/tellusa.v16i4.8993

Deng, T., Li, Q., Tseng, Z. J., Takeuchi, G. T., Wang, Y., Xie, G., et al. (2012) Locomotive Implication of a Pliocene Three-Toed Horse Skeleton From Tibet and its Paleo-Altimetry Significance. Proc. Natl. Acad. Sci. 109, 7374-7378. doi:10.1073/pnas.1201052109/-/DC 
Dettman, D. L., Fang, X. M., Garzione, C. N., and Li, J. J. (2003). Uplift-Driven Climate Change at $12 \mathrm{Ma}$; a Long $\delta^{18} \mathrm{O}$ Record From the NE Margin of the Tibetan Plateau. Earth Planet. Sci. Lett. 214 (1-2), 267-277. doi:10.1016/S0012821X(03)00383-2

Fang, X., Wang, J., Zhang, W., Zan, J., Song, C., Yan, M., et al. (2016). Tectonosedimentary Evolution Model of an Intracontinental Flexural (Foreland) basin for Paleoclimatic Research. Glob. Planet. Change. 145, 78-97. doi:10.1016/j.gloplacha.2016.08.015

Fricke, H. C., Clyde, W. C., and O'Neil, J. R. (1998). Intra-Tooth Variations in $\delta 18 \mathrm{O}$ (PO4) of Mammalian Tooth Enamel as a Record of Seasonal Variations in Continental Climate Variables. Geochimica et Cosmochimica Acta. 62, 1839-1850. doi:10.1016/S0016-7037(98)00114-8

Fricke, H. C., and O'Neil, J. R. (1996). Inter- and Intra-Tooth Variation in the Oxygen Isotope Composition of Mammalian Tooth Enamel Phosphate: Implications for Palaeoclimatological and Palaeobiological Research. Palaeogeogr. Palaeoclimatol. Palaeoecol. 126, 91-99. doi:10.1016/S00310182(96)00072-7

Fu, C., Qiang, X., Xu, X., Xi, J., Zuo, J., and An, Z. (2017). Late Miocene Magnetostratigraphy of Jianzha Basin in the Northeastern Margin of the Tibetan Plateau and Changes in the East Asian Summer Monsoon. Geol. J. 53 (S1), 282-292. doi:10.1002/gj.3047

Higgins, P., and MacFadden, B. J. (2004). "Amount Effect" Recorded in Oxygen Isotopes of Late Glacial Horse (Equus) and bison (Bison) Teeth From the Sonoran and Chihuahuan Deserts, Southwestern United States. Palaeogeogr. Palaeoclimatol. Palaeoecol. 206, 337-353. doi:10.1016/ j.palaeo.2004.01.011

Hough, B. G., Garzione, C. N., Wang, Z., Lease, R. O., Burbank, D. W., and Yuan, D. (2011). Stable Isotope Evidence for Topographic Growth and Basin Segmentation: Implications for the Evolution of the NE Tibetan Plateau. Geol. Soc. America Bull. 123 (1-2), 168-185. doi:10.1130/B30090.1

IAEA/WMO (2018). International Atomic Energy Agency Global Network for Isotopes in Precipitation Database. Available at: http://www.naweb.iaea.org/ napc/ih/IHS_resources_gnip.html.

Ji, J., Zhang, K., Qiang, T., Kou, X. H., Chen, F. N., Xu, Y. D., et al. (2010). Magnetostratigraphy of the Neogene Strata in Xunhua Basin, Qinghai Province. Earth Sci. J. China Univ. Geosci. 35, 803-810. (in Chinese). doi:10.3799/ dqkx.2010.093

Jiang, H., and Ding, Z. (2008). A 20 Ma Pollen Record of East-Asian Summer Monsoon Evolution from Guyuan, Ningxia, China. Palaeogeogr. Palaeoclimatol. Palaeoecol. 265, 30-38. doi:10.1016/j.palaeo.2008.04.016

Johnson, K. R., and Ingram, B. L. (2004). Spatial and Temporal Variability in the Stable Isotope Systematics of Modern Precipitation in China: Implications for Paleoclimate Reconstructions. Earth Planet. Sci. Lett. 220 (3-4), 365-377. doi:10.1016/S0012-821X(04)00036-6

Koch, P. L., Heisinger, J., Moss, C., Carlson, R. W., Fogel, M. L., and Behrensmeyer, A. K. (1995). Isotopic Tracking of Change in Diet and Habitat Use in African Elephants. Science. 267, 1340-1343. doi:10.1126/ science.267.5202.1340

Koch, P. L. (1998). Isotopic Reconstruction of Past continental Environments. Annu. Rev. Earth Planet. Sci. 26, 573-613. doi:10.1146/annurev.earth.26.1.573

Kohn, M. J. (2010). Carbon Isotope Compositions of Terrestrial C3 Plants as Indicators of (Paleo)Ecology and (Paleo)Climate. Proc. Natl. Acad. Sci. 107, 19691-19695. doi:10.1073/pnas.1004933107

Kohn, M. J., and Cerling, T. E. (2002). "12. Stable Isotope Compositions of Biological Apatite," in Phosphates-Geochemical, Geobiological, and Materials Importance. Reviews in Mineralogy and Geochemistry. Editors M. Kohn, J. Rakovan, and J. Hughes (Washington D.C: Mineralogical Society of America), v. 48, 455-488. doi:10.1515/9781501509636-015

Lease, R. O., Burbank, D. W., Clark, M. K., Farley, K. A., Zheng, D., and Zhang, H. (2011). Middle Miocene Reorganization of Deformation Along the Northeastern Tibetan Plateau. Geology. 39 (4), 359-362. doi:10.1130/G31356.1

Lease, R. O., Burbank, D. W., Gehrels, G. E., Wang, Z., and Yuan, D. (2007). Signatures of Mountain Building: Detrital Zircon U/Pb Ages from Northeastern Tibet. Geol. 35, 239-242. doi:10.1130/g23057a.1

Lease, R. O., Burbank, D. W., Hough, B., Wang, Z., and Yuan, D. (2012). Pulsed Miocene Range Growth in Northeastern Tibet: Insights from Xunhua basin Magnetostratigraphy and Provenance. Geol. Soc. America Bull. 124 (5-6), 657-677. doi:10.1130/B30524.1
Lee-Thorp, J., and van der Merwe, N. J. (1987). Carbon Isotope Analysis of Fossil Bone Apatite. S Afr. J. Sci. 83, 712-715.

Levin, N. E., Cerling, T. E., Passey, B. H., Harris, J. M., and Ehleringer, J. R. (2006). A Stable Isotope Aridity Index for Terrestrial Environments. Proc. Natl. Acad. Sci. USA. 103, 201-205. doi:10.1073_pnas.060471910310.1073/ pnas. 0604719103

Li, Y. F., Deng, T., Hua, H., Zhang, Y. X., and Wang, J. D. (2020). Isotopic Record of Palaeodiet of a 7.4 Ma Hipparionine Fauna From the Central Loess Plateau, Northern China: Palaeo-Ecological and Palaeo-Climatic Implications. Chem. Geol. 532, 120123. doi:10.1016/j.chemgeo.2019.119353

Lin, X., Chen, H., Wyrwoll, K.-H., and Cheng, X. (2010). Commencing Uplift of the Liupan Shan since 9.5Ma: Evidences from the Sikouzi Section at its East Side. J. Asian Earth Sci. 37, 350-360. doi:10.1016/j.jseaes.2009.09.005

Longinelli, A. (1984). Oxygen Isotopes in Mammal Bone Phosphate: a New Tool for Paleohydrological and Paleoclimatological Research? Geochimica et Cosmochimica Acta. 48, 385-390. doi:10.1016/00167037(84)90259-X

Luo, M. S., Lv, X. L., Zhang, K. X., Chen, F. N., Xu, Y. D., Chen, R. M., et al. (2010). Middle Miocene-Early Pliocene Ostracod Assemblages in the Xunhua Basin, Qinghai and Their Geological Significance. Acta Micropalaeontol Sinica. 27 (2), 125-134. (in Chinese).

Luz, B., Kolodny, Y., and Horowitz, M. (1984). Fractionation of Oxygen Isotopes Between Mammalian Bone-Phosphate and Environmental Drinking Water. Geochimica et Cosmochimica Acta. 48, 1689-1693. doi:10.1016/0016-7037(84) 90338-7

Ma, Y., Fang, X., Li, J., Wu, F., and Zhang, J. (2005). The Vegetation and Climate Change during Neocene and Early Quaternary in Jiuxi Basin, China. Sci. China Ser. D-earth Sci. 48, 676-688. doi:10.1360/03yd0110

MacFadden, B. J., and Ceding, T. E. (1994). Fossil Horses, Carbon Isotopes and Global Change. Trends Ecol. Evol. 9, 481-486. doi:10.1016/0169-5347(94) 90313-1

Miao, Y., Fang, X., Herrmann, M., Wu, F., Zhang, Y., and Liu, D. (2011). Miocene Pollen Record of KC-1 Core in the Qaidam Basin, NE Tibetan Plateau and Implications for Evolution of the East Asian Monsoon. Palaeogeogr. Palaeoclimatol. Palaeoecol. 299 (1-2), 30-38. doi:10.1016/ j.palaeo.2010.10.026

Molnar, P. (2005). The Growth of the Tibetan Plateau and Mio-pliocene Evolution of East Asian Climate. Palaeontol. Electro. 8 (1), 1-23. doi:10.1016/ j.palaeo.2009.11.002

Morgan, M. E., Kingston, J. D., and Marino, B. D. (1994). Carbon Isotopic Evidence for the Emergence of C4 Plants in the Neogene from Pakistan and Kenya. Nature. 367, 162-165. doi:10.1038/367162a0

Nelson, S. V. (2005). Paleoseasonality Inferred from Equid Teeth and Intra-Tooth Isotopic Variability. Palaeogeogr. Palaeoclimatol. Palaeoecol. 222, 122-144. doi:10.1016/j.palaeo.2005.03.012

Ogg, J. G. (2012). "5. Geomagnetic polarity time scale," in The geologic time scale 2012. Editors F. M. Gradstein, J. G. Ogg, M. D. Schmitz, and G. M. Ogg (Hoboken, NJ: Elsevier), 85-113.

Passey, B. H., Cerling, T. E., Perkins, M. E., Voorhies, M. R., Harris, J. M., and Tucker, S. T. (2002). Environmental Change in the Great Plains: an Isotopic Record from Fossil Horses. J. Geology. 110, 123-140. doi:10.1086/338280

Quade, J., Cerling, T. E., Barry, J. C., Morgan, M. E., Pilbeam, D. R., Chivas, A. R., et al. (1992). A 16-Ma Record of Paleodiet Using Carbon and Oxygen Isotopes in Fossil Teeth from Pakistan. Chem. Geology. 94, 183-192. doi:10.1016/s00092541(10)80003-8

Raymo, M. E., and Ruddiman, W. F. (1992). Tectonic Forcing of Late Cenozoic Climate. Nature. 359, 117-122. doi:10.1038/359117a0

Saylor, J. E., Jordan, J. C., Sundell, K. E., Wang, X., Wang, S., and Deng, T. (2018). Topographic Growth of the Jishi Shan and its Impact on Basin and Hydrology Evolution, NE Tibetan Plateau. Basin Res. 30, 544-563. doi:10.1111/bre.12264

Schleser, G. H., and Jayasekera, R. (1985). $\delta^{13} \mathrm{C}$-variations of Leaves in Forests as an Indication of Reassimilated $\mathrm{CO} 2$ from the Soil. Oecologia. 65, 536-542. doi:10.1007/BF00379669

Sharp, Z. D., and Cerling, T. E. (1998). Fossil Isotope Records of Seasonal Climate and Ecology: Straight from the Horse's Mouth. Geol. 26, 219-222. doi:10.1130/ 0091-7613(1998)026<0219:firosc >2.3.co;2

Sponheimer, M., Passey, B. H., de Ruiter, D. J., Guatelli-Steinberg, D., Cerling, T. E., and Lee-Thorp, J. A. (2006). Isotopic Evidence for Dietary Variability in the 
Early Hominin Paranthropus Robustus. Science. 314, 980-982. doi:10.1126/ science. 1133827

Stacklyn, S., Wang, Y., Jin, C.-z., Wang, Y., Sun, F., Zhang, C., et al. (2017). Carbon and Oxygen Isotopic Evidence for Diets, Environments and Niche Differentiation of Early Pleistocene Pandas and Associated Mammals in South China. Palaeogeogr. Palaeoclimatol. Palaeoecol. 468, 351-361. doi:10.1016/j.palaeo.2016.12.015

Sun, F., Wang, Y., Jablonski, N. G., Hou, S., Ji, X., Wolff, B., et al. (2021). Paleoenvironment of the Late Miocene Shuitangba Hominoids From Yunnan, Southwest China: Insights from Stable Isotopes. Chem. Geology. 569, 120123. doi:10.1016/j.chemgeo.2021.120123

Sun, F., Wang, Y., Wang, Y., Jin, C.-z., Deng, T., and Wolff, B. (2019). Paleoecology of Pleistocene Mammals and Paleoclimatic Change in South China: Evidence from Stable Carbon and Oxygen Isotopes. Palaeogeogr. Palaeoclimatol. Palaeoecol. 524, 1-12. doi:10.1016/j.palaeo.2019.03.021

Tipple, B. J., Meyers, S. R., and Pagani, M. (2010). Carbon Isotope Ratio of Cenozoic CO2: A Comparative Evaluation of Available Geochemical Proxies. Paleoceanography. 25 (3), 435-461. doi:10.1029/2009PA001851

Van der Merwe, N. J., and Medina, E. (1989). Photosynthesis and Ratios in Amazonian Rain Forests. Geochimica et Cosmochimica Acta. 53, 1091-1094. doi:10.1016/0016-7037(89)90213-5

Wang, F. L., Hong, H. L., Yin, K., Xu, Y. M., Zhang, K. X., and Zhang, J. Y. (2010). Clay Mineralogy and its Paleoclimatic Indicator of the Miocene Sediments of Xunhua Basin. Earth Sci. J. China Univ. Geosci. 35, 828-838. (in Chinese). doi:10.3799/dqkx.2010.096

Wang, Y., Cerling, T. E., and MacFadden, B. J. (1994). Fossil Horses and Carbon Isotopes: New Evidence for Cenozoic Dietary, Habitat, and Ecosystem Changes in North America. Palaeogeogr. Palaeoclimatol. Palaeoecol. 107, 269-279. doi:10.1016/0031-0182(94)90099-x

Wang, Y., and Deng, T. (2005). A 25 m.Y. Isotopic Record of Paleodiet and Environmental Change From Fossil Mammals and Paleosols from the NE Margin of the Tibetan Plateau. Earth Planet. Sci. Lett. 236, 322-338. doi:10.1016/j.epsl.2005.05.006

Wang, Y., Deng, T., and Biasatti, D. (2006). Ancient Diets Indicate Significant Uplift of Southern Tibet after Ca. 7 Ma. Geol. 34, 309-312. doi:10.1130/ G22254.1

Wang, Y., Deng, T., Flynn, L., Wang, X., Yin, A., Xu, Y., et al. (2012). Late Neogene Environmental Changes in the Central Himalaya Related to Tectonic Uplift and Orbital Forcing. J. Asian Earth Sci. 44, 62-76. doi:10.1016/j.jseaes.2011.05.020

Wang, Y., Kromhout, E., Zhang, C., Xu, Y., Parker, W., Deng, T., et al. (2008a). Stable Isotopic Variations in Modern Herbivore Tooth Enamel, Plants and Water on the Tibetan Plateau: Implications for Paleoclimate and Paleoelevation Reconstructions. Palaeogeogr. Palaeoclimatol. Palaeoecol. 260, 359-374. doi:10.1016/j.palaeo.2007.11.012

Wang, Y., Wang, X., Xu, Y., Zhang, C., Li, Q., Tseng, Z. J., et al. (2008b). Stable Isotopes in Fossil Mammals, Fish and Shells from Kunlun Pass Basin, Tibetan Plateau: Paleo-Climatic and Paleo-Elevation Implications. Earth Planet. Sci. Lett. 270, 73-85. doi:10.1016/j.epsl.2008.03.006

Wang, Y., Xu, Y., Khawaja, S., Passey, B. H., Zhang, C., Wang, X., et al. (2013). Diet and Environment of a Mid-Pliocene Fauna from Southwestern Himalaya: Paleo-Elevation Implications. Earth Planet. Sci. Lett. 376, 43-53. doi:10.1016/j.epsl.2013.06.014

Wynn, J. G., Sponheimer, M., Kimbel, W. H., Alemseged, Z., Reed, K., Bedaso, Z. K., et al. (2013). Diet of Australopithecus Afarensis From the Pliocene Hadar Formation, Ethiopia. Proc. Natl. Acad. Sci. 110, 10495-10500. doi:10.1073/ pnas. 1222559110

Xu, Z. L., Zhang, J. Y., Ji, J. L., and Zhang, K. X. (2015). The Mid-Miocene Pollen Record of the Xunhua Basin, NE Tibetan Plateau: Implication for Global Climate Change. Acta Geol. Sin-engl. 89 (5), 1649-1663. doi:10.1111/17556724.12571

Yang, R., Fang, X., Meng, Q., Zan, J., Zhang, W., Deng, T., et al. (2017). Paleomagnetic Constraints on the Middle Miocene-Early Pliocene Stratigraphy in the Xining Basin, NE Tibetan Plateau, and the Geologic Implications. Geochem. Geophys. Geosyst. 18, 3741-3757. doi:10.1002/ 2017GC006945

Yang, Y., Ye, C., Galy, A., Fang, X., Xue, Y., Liu, Y., et al. (2021). MonsoonEnhanced Silicate Weathering as a New Atmospheric CO 2 Consumption
Mechanism Contributing to Fast Late Miocene Global Cooling. Paleoceanogr Paleoclimatol. 36, e2020PA004008. doi:10.1029/2020PA004008

Ye, H., Zhang, K. X., Ji, J. L., Zhang, J. Y., Liang, M. Y., Xu, Y. D., et al. (2010). Major and Trace Element Characters of the Sediments and Paleoclimatic Evolvement During About 23.1-5.0 Ma in Xunhua Basin, Qinghai. Earth Sci. J. China Univ. Geosci. 35, 811-820. (in Chinese). doi:10.3799/dqkx.2010.094

Yin, A., and Harrison, T. M. (2000). Geologic Evolution of the Himalayan-Tibetan Orogen. Annu. Rev. Earth Planet. Sci. 28, 211-280. doi:10.1146/ annurev.earth.28.1.211

Yuan, D.-Y., Champagnac, J.-D., Ge, W.-P., Molnar, P., Zhang, P.-Z., Zheng, W.-J., et al. (2011). Late Quaternary Right-Lateral Slip Rates of Faults Adjacent to the lake Qinghai, Northeastern Margin of the Tibetan Plateau. Geol. Soc. America Bull. 123, 2016-2030. doi:10.1130/B30315.1

Yuan, D. Y., Ge, W. P., Chen, Z. W., Li, C. Y., Wang, Z. C., Zhang, H. P., et al. (2013). The Growth of Northeastern Tibet and its Relevance to Large-Scale continental Geodynamics: A Review of Recent Studies. Tectonics. 32, 1358-1370. doi:10.1002/tect.20081

Zachos, J., Pagani, M., Sloan, L., Thomas, E., and Billups, K. (2001). Trends, Rhythms, and Aberrations in Global Climate 65 Ma to Present. Science. 292 (5517), 686-693. doi:10.1126/science.1059412

Zhang, C., Wang, Y., Deng, T., Wang, X., Biasatti, D., Xu, Y., et al. (2009). C4 Expansion in the Central Inner Mongolia during the Latest Miocene and Early Pliocene. Earth Planet. Sci. Lett. 287, 311-319. doi:10.1016/ j.epsl.2009.08.025

Zhang, C., Wang, Y., Li, Q., Wang, X., Deng, T., Tseng, Z. J., et al. (2012a). Diets and Environments of Late Cenozoic Mammals in the Qaidam Basin, Tibetan Plateau: Evidence from Stable Isotopes. Earth Planet. Sci. Lett. 333-334, 70-82. doi:10.1016/j.epsl.2012.04.013

Zhang, R., Jiang, D., Liu, X., and Tian, Z. (2012b). Modeling the Climate Effects of Different Subregional Uplifts Within the Himalaya-Tibetan Plateau on Asian Summer Monsoon Evolution. Chin. Sci. Bull. 57, 4617-4626. doi:10.1007/ s11434-012-5284-y

Zhang, J. Y., Zhang, K. X., Ji, J. L., Luo, M. S., Chen, F. N., Xu, Y. D., et al. (2010). Oligocene-Pliocene Sedimentary Facies Analysis and Sedimentary Evolution of Xunhua Basin in Northeastern Margin of Qinghai-Tibet Plateau. Earth Sci. J. China Univ. Geosci. 35, 774-788. (in Chinese). doi:10.3799/dqkx.2010.091

Zhang, Y., Yue, L. P., and Cao, H. X. (2002). The Ecological Sequence of Hipparion Fauna in the Middle Reaches of the Yellow River during Neogene. Chin. Sci Bull. 47 (1), 79-82. doi:10.1360/02tb9016

Zhisheng, A., Kutzbach, J. E., Prell, W. L., and Porter, S. C. (2001). Evolution of Asian Monsoons and Phased Uplift of the HimalayaTibetan Plateau Since Late Miocene Times. Nature. 411, 62-66. doi:10.1038/35075035

Zin Maung Maung Thein, Takai, M., Uno, H., Wynn, J. G., Egi, N., Tsubamoto, T., et al. (2011). Stable Isotope Analysis of the Tooth Enamel of Chaingzauk Mammalian Fauna (Late Neogene, Myanmar) and its Implication to Paleoenvironment and Paleogeography. Palaeogeogr. Palaeoclimatol. Palaeoecol. 300, 11-22. doi:10.1016/j.palaeo.2010.11.016

Conflict of Interest: The authors declare that the research was conducted in the absence of any commercial or financial relationships that could be construed as a potential conflict of interest.

Publisher's Note: All claims expressed in this article are solely those of the authors and do not necessarily represent those of their affiliated organizations, or those of the publisher, the editors and the reviewers. Any product that may be evaluated in this article, or claim that may be made by its manufacturer, is not guaranteed or endorsed by the publisher.

Copyright $\odot 2021 \mathrm{Hu}$, Song, Sun, Huang, Luo, Ji, Lin, Algeo and Zhang. This is an open-access article distributed under the terms of the Creative Commons Attribution License (CC BY). The use, distribution or reproduction in other forums is permitted, provided the original author(s) and the copyright owner(s) are credited and that the original publication in this journal is cited, in accordance with accepted academic practice. No use, distribution or reproduction is permitted which does not comply with these terms. 